\title{
Кино как интертекст: от мифа города как праздничного разгула к апокалиптическим образам
}

Аннотация: В статье предпринята попытка выявить в рецепции кино мифологические подтексты, определяющие восприятие реципиентом конкретных фильмов, созданных многими режиссерами в разные эпохи. Эти подтексты активно влияют на сознание массовой публики, но при этом не осознаются. Содержанием массовой рецепции кино являются, в том числе, внекинематографические проявления коллективного бессознательного. В ней актуализируются ментальные проекции образов - архетипов, возникиих в разные эпохи истории культуры и связанные с утопическими представлениями, мифами, религиозными и фольклорными символами. Причем, проекциям коллективного бессознательного на кинематограф предшествуют проекции на город, которые затем переносятся и на кино. В конечном счете, кинематограф как таковой оказывается грандиозным интертекстом, в котором получает отражение история культуры как в ее осевом, так и в доосевом выражении. Предмет анализа в статье сводится к проекциям, ставшим реальными уже на ранних этапах истории кино. Для выявления мифологических, фольклорных и архетипических подтекстов в рецепции города, а затем и кино применяется методология таких научных дисциплин, как рецептивная эстетика, семиотика культуры, социология искусства, психология масс, психоанализ и аналитическая психология. Основными выводами проведенного исследования являются следующие: а. в структуре посещаемости раннего кино преобладают слои городского населения, сохраняющие в своем сознании фольклорные стереотипы; б. восприятие города происходит в соответствии с фольклорным архетипом праздничного разгула; в. Фольклорная аура, проецируемая вчерашним крестьянином - мигрантом на город, определяет отношение массовой аудитории к кино. Вклад автора в исследование кинорецепции связан с осознанием восприятия кинематографа в соответствии с мифом города, существовавшего в доиндустриальной культуре. Новизна исследования заключается в выявлении в сознании реципиентов специфических архетипов, в том числе, религиозного характера, актуализируемых в рецепции кинематографа 190о-1910-х годов.

Ключевъе слова: Кинематограф, город, миф, фольклор, рецепция, архетип, праздник, утопия, лиминальность, обряд.

Review: In his article Khrenov attempts to define mythological subtexts that define how particular movies and films created in different periods are perceived by the audience. According to the author, these subtexts have a strong influence on mass consciousness of public, however, public is usually unaware of them. Among other things the content of mass reception includes out-ofcinematographic manifestations of collective unconscious. Mental projections of archetypic images which came into existence in different periods of cultural history and connected with utopian visions, myths, and religious symbols are coming to the fore. Noteworthy that projections on the city are precede the projections of collective unconscious on the cinema; they are transferred into the cinema later on. Finally, the cinema in principal makes a colossal intertext in which cultural history is reflected both in its axial and pre-axial aspects. The scope of analysis comes down to the projections which become realistic already at early stages of cinematography history. To define mythological, folklore and archetypical subtexts of cinematography reception, the author of the article has used methodology of such academic disciplines as receptive esthetics, cultural semiotics, sociology of art, crowd psychology, psychoanalysis and analytical psychology. The main conclusions of the research are the following: a) the structure of the audience of early cinematograph was made up mostly of urban social groups which had folklore stereotypes in their consciousness; b) the city was perceived in accordance with the folklore stereotype of the festive revelry; c) the folklore aura around the city projected by the yesterday's peasant- migrant defines many things including how cinematography is perceived by mass audience. The author's contribution to the topic of cinematography reception 
is the cinematography perception in terms of the myth of the city that existed in the nonindustrial culture. The novelty of the research is caused by the fact that the author of the article describes specific archetypes including religious archetypes that exist in the mind of the audience (recipients) and became evident in the process of cinematography perception in the $1900-1910$.

Keywords: Myth, folklore, reception, archetype, holiday, utopia, liminality, rite, city, cinematography.

\section{1. Миф кино как слагаемое мифа города. Город как джунгли. Регресс в авантюрный дискурс.}

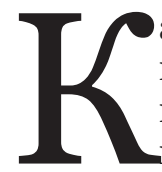

ак нами было показано в предыдущих статьях, миф города как праздничного разгула был спроецирован на кинематограф как явление городской культуры. Но этот образ города явно не исчерпывал всех мифологических смыслов. Попробуем выявить в этой проекции образы, которые столетиями внедрялись в сознание с помощью иконописи. Видимо, как можно предполагать, альтернативное отношение к городу уже не как к празднику, а как к апокалиптической реальности тоже связано с архетипами массового сознания. До того, как апокалиптические образы вытеснят проецируемую на город традиционную крестьянскую утопию, будет сформирован миф города, в котором торжествуют иррациональные стихии. Для выражения этого настроения требовались те формы, которые существовали уже на ранней стадии истории литературы.

Среди образов города может главенствовать не только образ города как утопического космоса, но и образ города как джунглей, что, кстати, способствовало становлению авантюрного романа. Но такой образ города касается и русского города, и связанного с ним образа кинематографа. Правда, этот вариант Ю. Цивьян связывает с европейским сознанием. «С первых дней европейское сознание - пишет он - включило кинематограф в контекст всеобъемлющей культурной метафоры: город как непроходимые джунгли» [21, с. 50].

Но этот образ города имеет отношение и к России. Видимо, метафора «город - джунгли» вызвала к жизни в эссе К. Чуковского образ кинозрителей как варваров (готтентотов, кафров и папуасов). Этот образ был использован, например, при оформлении фасадов раннего кинотеатра. Так, фасад кинотеатра на Арбате, принадлежащего Гехтману, украшался декорацией с изображением пустыни, пирамиды и львов. Р. Кайюа утверждает, что город провоцирует сильно действующее на воображение представление, которое трансформируется в миф, обладающий принудительной силой. А то, достоверен ли он, никто не интересовался. Город стал чем - то вроде механизма «остранения», который ранее связывался с удаленными в истории временами, а ныне, например, с таким городом, как Париж, в котором всегда может произойти все, что угодно. Эта городская среда, в которой развертывается жизнь каждого из нас, превратилась в таинственную среду.

Эти изменения настроений стали причиной трансформации не только романа, когда он возвращал к авантюрной схеме, но даже трансформации авантюрного романа в роман детективный. Р. Сеннет констатирует: в XIX веке в Париже и Лондоне в моду вошел детективный жанр. Почему? Это связано с новым восприятием города. «... Каждому, кто хотел разгадать загадки улицы, - пишет он - приходилось быть детективом» [12, с. 187]. Складывалось впечатление, что атмосфера леса или, еще точнее, джунглей как атмосфера романов $\Phi$. Купера стала атмосферой города. «Следует считать установленным - пишет Р. Кайюа - что эта метаморфоза города связана с переносом в городские декорации прерий и лесов Фенимора Купера, где любая сломанная ветка есть тревожный или обнадеживающий знак, где за каждым древесным стволом скрывается ружье врага или же лук незримого и бесшумного мстителя» [7, с. 122].

Вслед за погружением в атмосферу детективной истории, в которой центральной фигурой становится сыщик, приходит миф или, точнее, миф города. Называя публику готтентотами и дикарями, К. Чуковский пишет: «Но многомиллионному Готтентоту нужен Бог. Ему нужен вождь, за которым идти, ему нужен герой, пред которым склониться» [20, c. 37]. И этот герой приходит. Он создан по образу и подобию своего зрителя. Конечно, это не те герои, которые в начале XX века создает модернистский театр - не герои, например, популярного тогда Ибсена. «Но те великие мысли, великие страсти, то великое самоистя- 
зание, самосжигание души, которое мы знали в прежних героях - оно не для него. Он, который смеется, когда видит кастрюлю, надетую вместо шляпы, и плачет, когда теряет серебряный рубль - в самом деле не взять же ему себе в герои Бранда, Сольнеса или доктора Штокмана! Нет, самим богом предназначено, чтобы он своим идолом, своим героем, своим вождем и своим идеалом избрал Гороховое Пальто, сыщика Ната Пинкертона, - чтобы именно в этом образе он воплотил все доступные ему идеи о возможном величии души человеческой» [20, с. 38].

Первоначально город соотносился с окраинными кварталами, неведомыми улицами, непроходимыми катакомбами, а главное, с действием, разворачивающимся в этих местах ночью. Это именно этот повторяющийся в раннем кино сюжет преследования имел в виду К. Чуковский, когда писал следующее. «И потому - пишет он - какое множество в кинематографе картин, где человек убегает от человека, где один догоняет другого, где кто-нибудь стремится к какой-нибудь цели, одолевая физические преграды. Фальшивомонетчик бежит от полиции; он лезет по крыше, полицейские за ним, он катится с горы, полицейские за ним, он переплывает реки, озера, моря, океаны, - полицейские за ним, и все они стреляют, и делают друг другу засады, капканы, ловушки, и в этом для публики источник величайшего подъема души» [20, с. 25].

Постепенно мифологическим становится центр города. Атмосфера мифа становится уже характерной не только для ночи, но и для дня. Дневной свет не стирает таинственность города. Персонажами мифа становятся служащие официальных учреждений («Никто не ускользает от эпидемии, реальное повсюду заражено мифическим» [7, с. 125]. Так, как показывает Р. Кайюа, образ Парижа двоится. С одной стороны, это блестящая декорация, с другой, она управляется неведомыми силами. Эта декорация скрывает призрачный, ночной, неуловимый, таинственно - могущественный город. Именно такая среда порождает фантомные образы вроде Фантомаса, который появляется в маске и простирает над городом свою всемогущую длань. Над городом, - пишет Р. Кайюа - «простирает всемогущую длань исполин - Фантомас в маске, свежевыбритый и одетый во фрак и цилиндр, опершись ногой на какое - нибудь здание, в позе, которую позже все увидят на обложках иллюстрированных журналов» [7, с. 131]. Как известно, в начале XX века роман о Фантомасе был очень популярен. Первые его части выходили тиражом от 10 до 12 миллионов экземпляров [9, с. 183].

Перенесение в начале XX века атмосферы романов $\Phi$. Купера в городскую среду не прошло мимо внимания С. Эйзенштейна, необычайно внимательного к любому проявлению в искусстве регрессивной логики. Погоня сыщиков в детективных романах за преступниками воспроизводит, по мнению C. Эйзенштейна, охотничий инстинкт, который определяет действие и в романах $\Phi$. Купера. Цитируя Э. Сю, который на первых страницах своего романа «Парижские тайны» предупреждает своего читателя, что продемонстрирует нравы варваров, но уже других, а именно тех, что существуют в современных городах, С. Эйзенштейн замечает, что линия перенесения нравов девственных лесов в лабиринты больших городов в литературе становится традицией. «В этой связи интересно отметить, - пишет он - что увлекательной оказывается «охота» с обоих концов! Если есть романтика охотника, то, как оказывается, есть и романтика удирающего от охотника! Если есть романтика преследования по изломам линии оставленного следа, то есть и романтика в том, чтобы прочерчивать подобные изломы и, удирая, заметать следы» [23, с. 306]. Так, мир города вызвал к жизни и стимулировал развитие наиболее распространенных жанров кино - авантюрного и детективного.

\section{2. Трансформация образа города. От города как актуализации праздничного разгула к городу как вместилищу образов Апокалипсиса.}

Констатируя актуализацию в формах кино фольклорного сознания, мы тем самым реконструировали ту сторону массового сознания, что связана с языческими корнями, поскольку в сознании представителей индустриального общества, несмотря на старания церкви, оставалось еще много языческого. Однако в массовом сознании возрождался и еще один пласт мифологии, который связан с мифом в его христианском варианте. Противоречия, с которыми сталкивался в городе крестьянин мигрант, остудили его восторг перед городом как праздником. Реальный город перед ним представал уже не в образе праздничного разгула, а в апокалиптических образах. 
Таким, например, увидел город А. Белый. «Город убивает землю. Перековывает ее в хаотический кошмар. Город - мозг земли: мозг, развиваясь, оплетает тело стальной проволокой нервов. Он - паразит... - пишет А. Белый - Теперь можно сказать про город словами Апокалипсиса: «И поклонились зверю, говоря: кто подобен зверю сему и кто может сразиться с ним?.. И дана была ему власть над всяким коленом и народом, и языком и племенем. И поклоняется ему все живущее на земле, которых имена не написаны в книге жизни» [2, с. 357].

Как уже сказано, на уровне восприятия города как праздничного разгула смысл мифа как определяющего элемента рецепции не исчерпывается. Оказываясь в городском пространстве, мигрант очень скоро вынужден расстаться с утопизмом и с идеализацией города, a, в конечном счете, и с тем мифологическим образом, который возник в его сознании, когда он существовал в традиционной культуре. В городе торжествует не менее жесткая, но, может быть, даже еще более жесткая реальность, провоцирующая у мигранта то, что $\Phi$. Ницше назвал психологией ressentiment. Это озлобленность. Конечно, некоторые энергичные сельские жители, переселяясь в города, находили себя в предпринимательстве, превращаясь в ловких купцов. Но едва ли удача ожидала всех. Когда представший в городском образе жизни праздничный миф войдет в противоречие с реальностью, тогда город повернется своей обратной стороной и не только по отношению к крестьянину - мигранту.

Вот это иное отношение к городу выразят поэты - символисты. Например, В. Брюсов: «В городе я - как в могиле.../ Здания - хищные звери / С сотней несытых утроб! / Страшны закрытые двери: / Каждая комната - гроб!» [4, c. 177]. Или А. Блок: «Улица, улица.../ Тени беззвучно спешащих/ Тело продать, / И забвенье купить, / И опять погрузиться / В сонное озеро города - зимнего холода...» [3, с. 162].

Но такое восприятие города актуализируется позднее. Этому будет предшествовать утверждение, по крайней мере, двух типов рецепции города - рецепции, в которой проявляется классический тип места города как «золотого века» и рецепции, возникшей в узких, элитарных кругах, связанной с апокалиптическими настроениями и, соответственно, рецепцией города, в которой эти настроения будут определяющими. В какое - то время эти типы рецепции формируются обособлен- но, но наступает момент, когда тип рецепции, возникший в сознании элиты, распространяется и оказывается универсальным, выражающим мировосприятие самых разных социальных групп и субкультур.

Но чтобы апокалиптический тип рецепции стал универсальным и выражал сознание, в том числе, и крестьянина - мигранта должно было пройти время. Рожденный в крестьянской среде миф города как праздника должен был отступить перед реальностью города и распространением ressentiment. Когда это произойдет, можно уже говорить о том смыкании сознания крестьянина - мигранта, а ныне чаще всего фабричного с сознанием революционного авангарда, находящегося во власти религиозного восприятия революции. С. Булгаков очень точно диагностировал присутствие в духовном облике деятелей русской революции христианских черт. «Известная неотмирность, эсхатологическая мечта о граде Божьем, о грядущем царстве правды (под разными социалистическими псевдонимами) и затем стремление к спасению человечества - если не от греха, то от страданий - составляют, как известно, неизменными отличительные особенности русской интеллигенции... - писал С. Булгаков В этом стремлении к грядущему Граду, перед которым бледнеет земная действительность, интеллигенция сохранила, быть может, в наиболее распознаваемой форме черты утраченной церковности» [5, с. 33].

Вот эти черты утраченной, но вспыхнувшей в начале XX века религиозности, окрасившей политические настроения, интеллигенция смогла передать и массе, в сознании которой эти архетипы также дремали. Эту особенность также констатировал С. Булгаков. «Она (интеллигенция - Н. Х.) духовно оформляла инстинктивные стремления масс, зажигала их своим энтузиазмом, словом, была нервами и мозгом гигантского тела революции» [5, с. 29]. Начало XX века демонстрирует поразительную ситуацию - смыкание массового сознания с сознанием элиты. Как отмечала $\mathrm{X}$. Арендт, массовые движения для элиты оказывались необычайно привлекательными. «Несмотря на это расхождение между элитой и толпой, - пишет она - нет сомнения, что элита была довольна всякий раз, когда «дно» заставляло почтенное общество принимать себя на равной ноге. Представители элиты совсем не возражали заплатить ценой разрушения цивилизации ради забавы видеть, как те, 
кто в прошлом несправедливо был исключен из нее, силой прокладывает свой путь в общество» $[1$, с. 441].

В этой ситуации весьма любопытным было бы проследить, произведения какого типа в этот период оказываются в центре внимания публики. Обратим, например, внимание на популярность в русском театре спектаклей, поставленных по драмам норвежского драматурга Г. Ибсена. В особенности, драмы «Бранд», которая своим воскрешением образа, подобного древнему библейскому пророку, произвела, по выражению Л. Шестова, на русскую публику «совершенно потрясающее впечатление» [22, с. 17]. Собственно, ведь и психология ressentiment, которая столь значима для рефлексии Ф. Ницше, тоже в городе начала XX века не явилась впервые. По сути, к жизни она была вызвана функционированием многих социальных институтов, в том числе, религии. На протяжении столетий ее формировали все репрессивные институты.

Конечно, ressentiment - это с точки зрения $\Phi$. Ницше возникающие в результате действия репрессивных институтов аффекты ненависти и злобы. Но обычно эти аффекты являются скрытыми, латентными, выходя на поверхность сознания и утверждая себя в явной, т. е. революционной форме весьма редко. Но, оставаясь латентными, они, тем не менее, нуждались в изживании. Это изживание происходит в разных, в том числе, иллюзорных, виртуальных формах, в частности, в форме массовой культуры и, разумеется, кинематографа. Психология ressentiment проявляется в идеализации отверженных. По мнению $\Phi$. Ницше, ее носители воспринимают себя заслуживающими лучшей участи. Те же, кто считает себя лучшими - аристократы, дворяне, представители власти, естественно, должны быть наказаны. «Теперь они дают мне понять - пишет Ф. Ницше - что они не только лучше, чем сильные мира сего, господа земли, чьи плевки им надлежит лизать (не из страха, вовсе не из страха! Но понеже, Бог велит почитать всякое начальство), - что они не только лучше, но что и им «лучше», во всяком случае, однажды будет лучше» [10, с. 433].

Пожалуй, известная статья К. Чуковского, в которой публика первых кинотеатров представлена готтентотами, навеяна именно таким отношением к городскому плебсу, носителю аффектов ressentiment. Чего, кстати, нельзя сказать об отношении к кино А. Блока и А. Белого. Однако считаться с психологией ressentiment, как и с проявлением этой психологии в рецепции кино первых десятилетий все же приходится. Ведь именно эта психология будет питать миф уже в его апокалиптическом варианте. Такой ракурс позволит глубже понять то, что произойдет позднее, в эпоху появления и восхождения диктаторов. Сам Ф.Ницше, хотя и подразумевал под психологией ressentiment латентные аффекты озлобленности и мстительности («скрытые тлеющие аффекты мести и ненависти» [10, с. 431], тем не менее, улавливал ее связь с революционными вспышками. Так, по его мнению, во время Французской революции под ударами инстинктов ressentiment пало дворянство XУІІ и ХУІІІ столетия.

Но самое, пожалуй, интересное в ressentiment, - это то, что эта психология по отношению к апокалиптическим настроениям, сопровождающим движение к революционным вспышкам, не является нейтральной. Ведь носители этой психологи ожидают будущего блаженства. Но к нему можно прийти лишь через Страшный суд («Они именуют это «Страшным судом», пришествием их царства, «Царства Божия», - а пока что они живут «в вере», «в любви», «в надежде» [10, с. 434]. Не случайно $\Phi$. Ницше упоминает иоанновский Апокалипсис, связывая с ним тот самый аффект мести, во власти которого находятся носители ressentiment.

На этом характеристику носителей ressentiment, заполняющих первые синематографы, можно было бы и закончить, если бы не позднее признание К. Чуковского, вынужденного после катастрофической истории ХХ века, предысторией которой оказались первые десятилетия этого столетия, некоторые свои суждения уточнить. Последующая история прояснила и вывела в сознание то, что в начале XX века в массовом сознании лишь зрело. Спустя десятилетия, возвращаясь к своей статье 1910 года, К. Чуковский пишет: «Теперь через столько лет умудренные горьким историческим опытом, мы, к сожалению, хорошо понимаем, что в тогдашнем тяготении мирового мещанства к кровавым бульварным сюжетам таились ранние предпосылки фашизма» [20, с. 149].

Но еще раньше, в начале 30-х годов, т.е. задолго до второй мировой войны В. Райх будущую политическую катастрофу уже выводил из психологии человека массы, т.е. носителя ressentiment. По его мнению, фашизм - «это не дело рук какого - нибудь Гитлера 
или Муссолини, а выражение иррациональной структуры массового человека» [11, с. 20]. Собственно, глубокий диагноз фашизму удалось поставить уже В. Райху. Распространение идей национал - социализма им объясняется колебанием испытывающего страх перед свободой среднего класса. Эту идею и положил позднее 3. Кракауэр в своем психологическом исследовании о кино - «От Калигари до Гитлера» [8].

Таким образом, в городе вызываются к жизни и апокалиптические настроения. Coсредоточение массы в городском пространстве демонстрирует нечто такое, что невозможно было предсказать. Проблема даже не в том, что реальный город подтверждал созданный в доиндустриальном обществе мифологический образ города, а в том, что в России развертывался распад империи. И распад традиционной культуры, которая раньше не контролировала сознание и поведение горожанина в первом поколении. И распад имперской структуры, существовавшей в России несколько столетий. Этот распад в двойном смысле порождал крайние формы атомизации массы, что мигранту, покинувшему уют и неподвижность деревни, трудно было выносить. Это острое ощущение одиночества в городе провоцирует новые мифологические смыслы.

Если реальность связана с тем, что Э. Дюркгейм называет социальной аномией, то политическая элита уже перестает быть авторитетом. Власть теряет кредит доверия. На этом фоне понятен поиск массой новых лидеров. Ими уже не могут быть привычные имена политиков. Новые авторитеты приходят с улицы. У них сложные отношения с властью. Это мятежники, бунтари, такие, как фабричный паренек Максим в известной кинотрилогии Г. Козинцева и Л. Трауберга. Это выразители того ressentiment, во власти которого находится масса. Носители такого образа всегда существовали не только в мифологическом, но и в фольклорном сознании. Их называли «разбойниками». Если в сознании людей такие архетипические образы существовали и раньше, то они могут возрождаться. В первые десятилетия XX века создавшаяся ситуация предельной атомизации жестко диктовала необходимость в появлении таких харизматических лидеров, которые бы воспроизводили фольклорные образы «разбойника». Без них масса продолжала оставаться бесструктурным, анонимным и легко воспламеняющимся образованием. Такой лидер мог сплотить мас- су, сделать ее могущественной. Только лидер наделяет массу новым качеством.

Как доказывает Г. Лебон, в массе индивид отключает сознание и погружается в бессознательное. Это ситуация, когда грань между воображаемым и реальным исчезает. В этой ситуации вспыхивает чувство утопии. Но это уже утопия другого качества. Ressentiment трансформируется в революционное настроение. Возникает вопрос: если, начиная с 1917 года, в России произошло то, что произошло, то можно ли считать, что кино первых десятилетий позволяет улавливать движение к политической катастрофе? Можно ли на основании анализа сюжетов раннего российского кинематографа судить о том, что первоначально то, что произойдет в политической истории, получит выражение в кинематографических образах? Такой вопрос был поставлен 3. Кракауэром применительно к немецкому кино в исследовании «От Калигари до Гитлера». Но он был поставлен применительно к немецкому кино. И на этот вопрос 3. Кракауэр ответил утвердительно.

А как обстоит дело с российским кино? Конечно, чтобы на этот вопрос ответить, необходимо привлекать многие свидетельства и не ограничиваться исключительно кино, но, например, привлекать поэзию, театр, литературу. Может показаться, что, привлекая поэзию и театр, мы касаемся уже не массовых, а элитарных искусств и того, что для выявлениях архетипов массового сознания они могут оказаться не самыми значимыми. Но это не совсем так. Как утверждает X. Арендт, в ситуации первых десятилетий XX века получила выражение весьма примечательная особенность - интеллигенция увлекалась массовыми движениями и разделяла массовые настроения. Здесь важно сказать о созвучности массового сознания и сознания элиты. Это особая и весьма значимая тема, которая была затронута X. Арендт. «Скоро открылось - пишет Х. Арендт - что высококультурные люди особенно увлекаются массовыми движениями и что вообще в высшей степени развитый индивидуализм и утонченность не предотвращают, а в действительности иногда поощряют саморастворение в массе, для коего массовые движения создавали возможности» [1, с. 421].

Дело в том, что, несмотря на агрессивность и вульгарность массы, что провоцировало в сознании мыслящих людей воспоминание о высказанной Д. Вико, а затем и Ф. Ницше идее постоянно возвращающегося в истории 
варварства, все же элиту массовые движения привлекали. Это вторжение массы в историю некоторых представителей элиты не отталкивало, а привлекало. Это можно проиллюстрировать, в том числе, и на примере тех интеллектуалов, художников и поэтов, которые часто появлялись в синематографах. Среди таких были А. Блок и А. Белый. Любопытно, например, констатировать перекличку апокалиптических образов, характерных для некоторых русских сект и образов этого рода, в поэзии символистов. Понятно, что между символистами и хлыстами были контакты [24]. Но созвучность некоторых образов в сектантских и символистских кругах не может не обратить на себя внимание в связи с апокалиптическими настроениями. В русской культуре всегда были эпохи активизации апокалиптических образов [19]. Это в особенности касается переходных эпох. В прошлом такая активизация развертывалась в религиозных формах. Позднее она предстает в формах революционных, т. е. политических. Но она также предстает и в художественных формах.

Чем ближе к революции 1917 года, тем очевидней активность образов Апокалипсиса. Об этой созвучности восприятия революции образам Апокалипсиса писал С. Булгаков. Такие образы активны, когда народ оказывается в лиминальной ситуации, т.е. в ситуации упразднения социальной иерархии и социальной структуры и устремлен к ожиданию преображения, наступления нового эона или исторического цикла. Касаясь возрождаемых в России апокалиптических настроений, С. Булгаков в 1910 году писал: «Рождение нового эона сопровождается муками родов, историческими и космогоническими. Апокалипсисы отводят много места описанию этих мессианских мук, а вместе знамений в природе и в истории. Омрачение солнца, луны и непорядки в звездном мире, появление в небе мечей, всадников и пешеходов, смятение в природе, появление солнца ночью, луны днем, кровавая роса на деревьях, осоление пресной воды и т.д. и т.д. ознаменуют наступление конца мира. В человеческом обществе такое же расстройство и распад всех связей, торжество греха и безбожия. Как бы охваченные безумием, люди начинают истреблять друг друга. Восстает народ на народ, царство на царство, будут землетрясения и голод. Все эти бедствия становятся тем сильней, чем ближе конец; наконец, появляется личное воплощение зла, антихрист или белиар, представление о кото- ром имеет, как известно, глубокие ветхозаветные корни. Силы зла с наибольшим ожесточением ополчаются против избранного народа и святого города. И лишь в последнюю минуту окончательного отчаяния, невыносимой муки, полного торжества зла наступает развязка исторической драмы. Появляется мессия, который побеждает антихриста, собирает рассеянных сынов Израиля, восстанавливает Иерусалим и открывает тысячелетнее царство. На заднем плане этой картины помещается эсхатологическая перспектива: воскресение мертвых, страшный суд и окончательный приговор над праведниками и грешниками, обновление мира, царство Божие, ожиданием которого проникнута вся эта эпоха» [6, с. 89]. По сути, С. Булгаков описывает мифологический подтекст актуальных для начала XX века настроений. Но, собственно, суждения философа как раз эту цель и преследовали.

\section{3. Передвижение мифа из рецепции в поэтику. От мифа в кинематографической форме к мифологии политической истории.}

Так, обращаясь к ранней эпохе функционирования кино, мы обнаружили, что изучение до некоторых пор неосвоенной проблематики его рецепции позволяет выявить миф в его кинематографических формах. Первоначально он определяет рецепцию кино, а затем становится основой его поэтики. Осмысленные нами феномены нам остается включить в те представления, что сложились в эстетике. Чем же кинематограф располагал на раннем этапе своего развития и что он на последующих этапах утерял? А то, что ранний кинематограф возвращал к архаическим эпохам, когда возникновение того, что мы знаем как язык в его вербальных формах, ставший универсальным языком человечества, только начиналось. И язык еще не успел оторваться от предметно - чувственных форм. Коммуникация развертывалась не с помощью произвольных знаков - слов, а с помощью изображений. Это как раз то, что С. Эйзенштейн находил в китайской и японской писыменности, в иероглифах, приходя к отождествлению киноязыка с иероглифической письменностью.

Но важно понять феноменологический смысл утрачиваемого, но возрождаемого в формах кинематографа языка. В своей философской системе Гегель представил это самое 
раннее состояние Духа, когда у него возникает потребность в передаче пока еще неясного ему самому смысла. Духу пока и смысл не совсем ясен, да и вообще непонятно, какие способы можно избрать для выражения не до конца ясных смыслов. Понятно, что возникающее на этой фазе что - то вроде языка связано с обращением к каким - то предметам, вещам, явлениям физической реальности. Тут - то на первый план как раз и выходит люмьеровская парадигма в практике и теории кино. Для какой-то пробуждающейся мысли Дух мог использовать самые разные способы коммуникации. Одни и те же вещи и предметы могли выражать разные смыслы. Эту стадию в истории становления Духа Гегель называет символической фазой, которая в последующей истории человечества преодолевалась. Последовательно возникали следующие стадии.

Но вот ведь какая удивительная вещь происходит с кинематографом. Представляя суперсовременное явление, соответствующее установкам индустриальной цивилизации, кино в то же время возвращало к самой архаической фазе становления познания, языка и коммуникации, которая есть то, что Гегель назвал символической фазой в истории Духа. Но, возвращая к этой фазе, кино уже тем самым реабилитировало мифологическую стихию, поскольку символ - этот тот способ коммуникации, который адекватен выражению и сверхчувственной, и мифологической реальности. Так, что лингвистический аспект кино оказался тоже следствием мифологического сознания. Ведь на этой фазе еще не существовало ни логического, ни художественного познания в их самостоятельности и раздельности. На символической фазе всякое познание было мифологическим и никаким более.

Возвращая человечество к ранней, т.е. предметной форме языка, кино тем самым не могло не реабилитировать самую раннюю форму сознания - мифологическую. Но ведь что такое миф, который, как ни пытались его приручить письменная и, в особенности, печатная литература, все же сохраняет самостоятельность. И на мифологическом уровне развертывается стихия мышления массового человека. Чтобы ответить на этот вопрос, следует еще иметь информацию, в какой ситуации на рубеже XIX - XX веков этот массовый человек оказывался.

Ядром мифа, несомненно, является то, что теоретики мифа называют «культурным героем». Это та самая фигура, на которую мас- са проецирует все свои надежды и чаяния. Тем более, масса в ситуации распада доиндустриального общества, которое мы обычно называем традиционным обществом, и в ситуации одновременно распада империи, в которой до сих пор человеку было, несмотря на отсутствие свободы, все же комфортно. Употребляя понятие «человек массы», мы опять же должны исходить из принципа историзма. Человек массы раньше не существовал. Он появляется как раз в эпоху надлома и распада и доиндустриального общества, и империи. Распад империи означает и уход с политической арены тех лидеров, которые обладали каким-то авторитетом и которых привыкли наделять сакральным смыслом. Прежде всего, конечно, такой фигурой был сам император - первое лицо государства как сакральная фигура.

Но дело в том, что уже на протяжении всего XIX века в России нарастали и распространялись настроения ressentiment, которые сакрализации элиты явно не способствовали. Недовольство и озлобление сосредоточившейся в городах массы нарастало. Затрагивая вспыхивающие настроения ressentiment, P. Сеннет объяснил, что амбивалентное отношение к городу объясняется недоверием к власти, которую составляли люди, недостойные в глазах массы пребывания на вершине пирамиды. Из - за их аморальных действий многие способные люди не могут занять в обществе достойного места. Однако этих недостойных людей, пробившихся к власти, в силу особенностей безличной экономики, трудно идентифицировать. «Когда власть становится бюрократизированной, как многонациональной корпорации, - пишет Р. Сеннет - очень трудно установить ответственность определенной личности за какое - либо действие. При развитом капитализме власть делается невидимой; организации защищают себя от подотчетности с помощью крайней административной сложности» [12, с. 316].

Так возникает миф о тайном сообществе пробравшихся к власти и терроризирующих население города преступников. Распространяющаяся невидимость реальной власти порождает миф о заговоре нечестных людей, пробравшихся во власть и держащих все население под контролем. Так возникает атмосфера, благоприятная для расцвета авантюрного и детективного жанра. «Но в верхах есть люди, - пишет Р. Сеннет - не обладающие талантом; они выживают благодаря своим связям, 
благодаря тому, что не допускают в свой круг талантливых людей. Таким образом, если вы находитесь на нижней ступени лестницы, то отсутствие статуса - не ваша вина, у вас просто отобрали то, что было бы вашим по праву» [12, с. 317].

Это приводило к тому, что отсутствие в реальности идеальных фигур, связанных с социальной структурой, социальными ролями и социальной иерархией, провоцировал появление таких фигур в коллективном воображении и сознании. Но, возникая в массовом сознании, они затем получали выражение в художественных образах. Здесь важно то, что в таких харизматических фигурах была потребность. В своем специальном исследовании, посвященном психологии масс, 3. Фрейд отметит, что масса остается распыленной и неорганизованной, а потому и способной на преступления, до тех пор, пока не возникнет фигура, в которой она почувствует нового «культурного героя», способного ее вывести из состояния неопределенности и неустойчивости. Конечно, такой культурный герой обязательно находится в самой политической истории. Не случайно Р. Сеннет выходит на обсуждение харизматической личности, которая, критикуя власть, выражает ressentiment массы. Но этому предшествуют длительные процессы.

Во - первых, сама масса должна стать реальностью, что и происходит на рубеже XIX - XX веков. Во - вторых, она должна ощутить все эмоции, вытекающие из ее атомизированного состояния, что означает, несмотря на скученность и массовость ее существования в городе, одиночество каждого и всех. Вот в новом пространстве существования это ощущение одиночества и бесприютности исчезает на время, когда люди оказываются в синематографе. «В больших городах под внешним покровом культуры - пишет А. Топорков - конечно, таится еще много варварства, дикости, не облагороженной и не преображенной сознательным творчеством человека, свободным его совершенствованием. Есть в больших городах современности много неустойчивых душ, «деклассированных элементов», со сломленными основами нравственного и даже бытового уклада, много людей, измолотых и изглоданных судьбой, попавших под колесницу жизни, раздавленных ее колесами. Из этих групп и элементов населения столиц образовалась кинематографическая публи- ка. Бездомные и бедные, они шли на сверкание электрических огней, чтобы согреться зимой в пышных и доступных залах, чтобы забыться в сменах скользящих теней, побыв там в течение полутора часа» [13, с. 44].

Собственно, именно это обстоятельство забыться в смене скользящих теней и подтверждает уже процитированный нами тезис М. Маклюена. Но этого недостаточно. Постепенно эти скользящие на экране тени провоцируют активность массы. Они становятся запальником для активизации воображения массы. Поэтому здесь возникает новый уровень анализа нашего предмета. В - третьих, следовательно, начинается активность массового сознания. В нем активизируются те уровни сознания, в которых актуализируется стихия устной или фольклорной культуры. Пока эти фольклорные и мифологические образы являются реальностью лишь массового сознания. До некоторого времени они оказываются на положении виртуальных образов. Они свидетельствуют об актуализации вытесненных на периферию ранних или устных уровней мышления. Но они требуют объективации и институционализации, что начинают ощущать и режиссеры, но в особенности, конечно, продюсеры, заинтересованные в том, чтобы их расходы на производство фильмов не только окупались, но и помогали увеличивать состояния.

Кинематограф включался в тот предпринимательский бум, который имел место как раз в этот период как исходная точка становления общества потребления. И кино, разумеется, приобретало товарный вид. Таким образом, чтобы сформировалась определенная рецепция фильма, в массовом сознании должен актуализироваться какой - то образ, характерный для устной культуры, для мифа. Пока он для фильма еще будет внешним, и его нельзя вывести непосредственно из сюжета и жанра. Но, тем не менее, он был активным, проецировался на изображение и определял рецепцию. Оставалось этот образ оформить в соответствующие сюжеты и жанры. Предпринимательский бум способствует перетеканию форм мифологического сознания в кинематографические формы на уровне сюжетов и жанров. Начинается институционализация тех стереотипов и образов устной культуры, которые сохранялись на уровне массового сознания. Все свидетельствует о том, что кинематограф, стано- 
вясь социальным институтом, вписывается в историю искусства в ее новом виде. Но, более того, в психологию политической истории. Первоначально представшие в образах кино некоторые мифологические фантомы затем входят в реальность, объективируясь в образах представителей политической элиты. Мифология начинает представать уже не только в образах города и в образах кино, но и в образах политической истории.

\section{Библиография:}

1. Арендт Х. Истоки тоталитаризма. М., 1996., с. 441.

2. Белый А. Город // Белый А. Арабески., М., 1911.

3. Блок А. Собрание сочинений в 8 т., т. 2., М-Л., 1960.

4. Брюсов В. Собрание сочинений в 7 т., т. 1., М., 1973.

5. Булгаков С. Героизм и подвижничество // Вехи. Сборник статей о русской интеллигенции., М., 1990.

6. Булгаков С. Апокалиптика, социология, философия история, социализм // Русская мысль., $1910 .$, №6.

7. Кайюа Р. Миф и человек. Человек и сакральное. , М., 2003.

8. Кракауэр 3. Психологическая история немецкого кино. От Калигари до Гитлера. М., 1977.

9. Массовая литература и кризис буржуазной культуры Запада., М., 1974.

10. Ницше Ф. К генеалогии морали // Ницше Ф. Сочинения в 2-х т., т. 2., М., 1990.

11. Райх В. Психология масс и фашизм., СПб., 1997.

12. Сеннет Р. Падение публичного человека., М., 2002.

13. Топорков А. Кинематограф и миф // Кинематограф. Сборник статей., М., 1919.

14. Хренов Н. Развлечение в эпоху смены культурных циклов: модель фольклора // Развлечение и искусство., СПб., 2008.

15. Хренов Н. Избранные работы по культурологии. Культура и империя., М., 2014.

16. Хренов Н. Публика в истории культуры. Феномен публики в ракурсе психологии масс., М., 2007.

17. Хренов Н. Миф в формах кинематографа как слагаемое имперской идентичности // Теория художественной культуры. Выпуск 15., М., 2014.

18. Хренов Н. Архетипы православного мессианизма в русском кино // Киноведческие записки. Выпуск 82. M., 2007.

19. Чилингаров А. Влияние Дюрера и современной ему немецкой графики на иконографию поствизантийского искусства // Древнерусское искусство. Зарубежные связи. М., 1975.

20. Чуковский К. Собрание сочинений в 6 т., т. 6., М., 1969.

21. Цивьян Ю. Историческая рецепция кино. Кинематограф в России. 1896-1930., Рига.

22. Шестов Л. Победы и поражения (Жизнь и творчество Г. Ибсена) // Русская мысль. 1910., № 4.

23. Эйзенштейн С. Избранные произведения в 6 т., т. 3., М., 1964.

24. Эткинд А. Хлыст. Секты, литература и революция., М., 1998.

\section{References (transliterated):}

1. Arendt Kh. Istoki totalitarizma. M., 1996., s. 441.

2. Belyi A. Gorod // Belyi A. Arabeski., M., 1911.

3. Blok A. Sobranie sochinenii v 8 t., t. 2., M-L., 1960.

4. Bryusov V. Sobranie sochinenii v 7 t., t. 1., M., 1973.

5. Bulgakov S. Geroizm i podvizhnichestvo // Vekhi. Sbornik statei o russkoi intelligentsii., M., 1990.

6. Bulgakov S. Apokaliptika, sotsiologiya, filosofiya istoriya, sotsializm // Russkaya mysl'., 1910., №6.

7. Kaiyua R. Mif i chelovek. Chelovek i sakral'noe., M., 2003.

8. Krakauer Z. Psikhologicheskaya istoriya nemetskogo kino. Ot Kaligari do Gitlera. M., 1977.

9. Massovaya literatura i krizis burzhuaznoi kul'tury Zapada., M., 1974.

10. Nitsshe F. K genealogii morali // Nitsshe F. Sochineniya v 2-kh t., t. 2., M., 1990.

11. Raikh V. Psikhologiya mass i fashizm., SPb., 1997.

12. Sennet R. Padenie publichnogo cheloveka., M., 2002.

13. Toporkov A. Kinematograf i mif// Kinematograf. Sbornik statei., M., 1919.

14. Khrenov N. Razvlechenie v epokhu smeny kul'turnykh tsiklov: model' fol'klora// Razvlechenie i iskusstvo., SPb., 2008. 
15. Khrenov N. Izbrannye raboty po kul'turologii. Kul'tura i imperiya., M., 2014.

16. Khrenov N. Publika v istorii kul'tury. Fenomen publiki v rakurse psikhologii mass., M., 2007.

17. Khrenov N. Mif v formakh kinematografa kak slagaemoe imperskoi identichnosti // Teoriya khudozhestvennoi kul'tury. Vypusk 15., M., 2014.

18. Khrenov N. Arkhetipy pravoslavnogo messianizma v russkom kino // Kinovedcheskie zapiski. Vypusk 82., M., 2007.

19. Chilingarov A. Vliyanie Dyurera i sovremennoi emu nemetskoi grafiki na ikonografiyu postvizantiiskogo iskusstva // Drevnerusskoe iskusstvo. Zarubezhnye svyazi. M., 1975.

20. Chukovskii K. Sobranie sochinenii v 6 t., t. 6., M., 1969.

21. Tsiv’yan Yu. Istoricheskaya retseptsiya kino. Kinematograf v Rossii. 1896-1930., Riga.

22. Shestov L. Pobedy i porazheniya (Zhizn’ i tvorchestvo G. Ibsena) // Russkaya mysl’. 1910., № 4.

23. Eizenshtein S. Izbrannye proizvedeniya v 6 t., t. 3., M., 1964.

24. Etkind A. Khlyst. Sekty, literatura i revolyutsiya., M., 1998. 